\title{
EXORDIUM
}

\section{FROM KNOWLEDGE TO KNOWLEDGE OF PRACTICE. THE RELATIONSHIP OF HELP AS A PATH OF CONSTRUCTION OF THE LIFE PROJECT di Vito Balzano}

What elements can characterize the construction of the life project on the basis of knowledge of educational practice today? This is the problem that describes this contribution, and which aims to investigate, on the basis of the categories proper to social pedagogy, possible practical actions of training of the citizen. The example of volunteering, as a practice of giving, but above all the redefinition of knowledge of the practice, and the moral category of solidarity, open new and important scenarios for the young generations that at the same time demand a hermeneutic, dynamic and modifiable place. They educate the meeting, in that perspective that allows us to recognize in others the differences that characterize the aspect of equality of each person in the relationship with themself and with others.

Quali elementi possono oggi caratterizzare la costruzione del progetto di vita sulla scorta dei saperi della pratica educativa? $\grave{E}$ questo il problema che descrive il presente contributo, e che mira a indagare, sulla scorta delle categorie proprie della pedagogia sociale, possibile azioni pratiche di formazione del cittadino. L'esempio del volontariato, come pratica di dono, ma soprattutto la ridefinizione dei saperi della pratica, e la categoria morale della solidarietà, aprono nuovi e importanti scenari per le giovani generazioni che nella contemporaneità chiedono un luogo ermeneutico, dinamico e modificabile. Educare all'incontro, quindi, in quella prospettiva che ci permette di riconoscere nell'altro le differen- 
ze che connotano l'aspetto di uguaglianza di ogni persona nel rapporto con sé stessa e con l'altro.

\section{Knowledge of the human: from Conflict to Solidarity}

Contemporary philosophy encompasses several and multiple strands among which, more and more current, appear to be those attributable to the moral category of solidarity. From here it moves to a reflection, in truth already channeled in the paths of educational research now for several years, which sees the analysis and the re-proposal of new models of welfare, and a different idea of volunteering, the keystone of a theoretical and practical elaboration of liberal democracy, through the analysis of knowledge of the practice. The current scenarios of pedagogy in Italy and in Europe are marked by profound structural changes concerning the state of welfare and the transition from the conception of an assistential state to the idea of an active welfare state. From this perspective, the concept of active society based on the free choice and responsibility of the person emerges; the emphasis is, therefore, on the centrality of the human subject as an individual, on his ability to be and know how, but also on the practical implications. The idea of active social status refers to a particular vision of the relationship between citizen and state, between individual good and common good, between individual and collective responsibility.

The theory of conflict, at the basis of human revolutions, today allows a different vision of the concept of solidarity, whose ethical-political validity must be safeguarded without neglecting true objective autonomy. Hence a twofold dimension of moral reflection: the first refers to the inamendable of the real, or a manifestation as "friction", as something that opposes the subject, resists him; the second refers to the concept of irrevocability of historical events, or not arbitrariness in the interpretation of an event that, in fact, belongs to history (Elia, 2016, p. 19). 
In the knowledge and information societies, the culture and organization of work, individual and social needs are increasingly articulated and complex: the interdependencies and inextricability of all these aspects are very interesting in the educational scenarios of the XXI century, starting from the assumption that education is the function of providing the human subject the map to orient itself in a complex world and in constant transformation, and the compass needed to to deal effectively with the risks and uncertainties that characterize everyday life. This presupposes, however, that the condition of postmodern knowledge, to put it with changes, is a new condition, a condition marked, in depth, by at least four individuable characteristics: in exponential growth, in epistemology condition as the internal frontier of the coordination and innovation of the various types of knowledge, their increasing social presence and/or social productivity, and, finally, their critical and metacritical reflexivity (Cambi, 2004, p. 51). The integration between the different areas of knowledge, therefore, marks a radical transformation of the way of conceiving competence with a view to rethink the paradigms of traditional formation, characterised by a fordist vision of society and Of the organization of work. It is here that moves the first and important step: the study on the complexity of the subject lowered in the real context of the work world, where often they are rewarded, almost as if it were a macro area, the knowledge and the experiences of the person without too much distinction. The global market, which characterizes the societies of complexity, needs people able to solve new and complex problems for which they need inventiveness and creativity, but above all requires that ability to discern the pedagogical sense of work and its reference contexts (Baldacci, 2010).

Domineering back, as it is now for several decades, is the necessity of a new idea of welfare detached from traditional models and more oriented towards a relational and humanitarian plan. For example, also the europeanist question, which has long been based in the quicksand of a still awkward governance, fixed on rules of practice of social policies that travel at much slower 
speeds than the evolution of contemporary society and of the multi-dimensional and multi-ethnic context that characterizes the old continent, today requires an essential re-reading of the irreplaceable value of the different socio-cultural components, also towards new approaches to welfare and the interpretation of human development, the theme of inclusion and the realization of the democratic idea. It is the sense of the future that must be traced beyond the drift of folding in oneself and towards the past. On this front it will be interesting to dwell, briefly, also on the intergenerational dialogue between scholars, a constant confrontation between the disciplines and the openness to emerging research in the widest possible context.

It is known, in fact, that a system of welfare lays the person at the center; however, here it concerns seeing the person in their transformative dynamics and to observe if and how this is possible, using the pedagogy no longer in a broad sense but through the category of responsibility that allows us, at the most, to observe the relational dimension and the expansives spaces in their entirety. A pedagogic knowledge, therefore, that allows us to reformulate a new and different idea of welfare and, above all, a new reading of volunteering not simply as a third sector but as a support and belp to the action of the state in socio-political field.

\section{From the knowledge of practice to the practice of volunteering}

From the premises of a generative and relational welfare, incardinated of the constructs of the social pedagogy, according to which «all the subjects of the private social collaborate and coordinate their efforts for the construction of new ligatures, of new plots among the actors involved» (Balzano, 2017, p. 108), is born an idea of voluntary new distinct from the classic vision but that, from this very one, recovers a fundamental starting point: we are faced with a practical, intentional and, not less, responsible act, which presupposes people to give not only in a material capacity but, above all, from an ethical point of view. In a 
pedagogical capacity, in fact, the questions on the possible foundations of the educational relations in the time of the ethical fragmentation, the reduction of value choices and the incoherence of the action call for innovative answers able to correspond to different stories, needs, and contexts. A conscious knowledge that opens up to the evaluation of a transformation of the person happens through the evaluation of two different spatial areas: an upstream space, where we can focus on the concrete possibility of reactivating subjects with potential reserves elevated, as for such as non-occupied, integrated boxes, etc.; consequently, a space downstream where attention will be captured by the professionalism dedicated to the care towards the wide ranges of human poverty still exists today. Fundamental passages describing a different vision of the practical meaning of volunteering, in a historical-cultural phase in which the mechanism that regulates the relationship between rights and duties, the possibility of desire and the recognition of limits that reality and relationships asks us, leaving the person in a new dimension of different recognition of the community and generational function of education. But what binds the two areas is soon understood if you think of a solidarity that is part of humanity and moral obligation, where «human nature cannot in any way subsist without individuals joining in society, and this association would never, if it were not taken into account the laws of fairness and justice» (Hume, 1992, p. 128).

A practical knowledge is attributable to the gift intended as a gift, or on that relationship that binds donor and recipient; in fact, depending on the type of relationship, the quality and extent of the gift itself varies. Think of the economic value it possesses, a weight even in terms of money; the gift is the gift that has a precise price, and the calculation of the price, however, excludes an essential and decisive factor of giving: gratuity, which seems to be less where the market dominates. With the term donate, therefore, one should refer to the ability of the individual to give to others freely and without useful compensation or pleasure; instead, the link between gift and gratuity is not discounted, given 
that the gift is not always and only free or excludes a priori the exchange, indeed, as Mauss tells (2002), the gifts have distinguished themselves, in the archaic communities, as «total social facts» since «phenomena [...], at one time, legal, economic, religious and even aesthetic, morphological, etc.» able to put in motion «the totality of society and its institutions» on the basis of the exchange (p. 134). Knowing how to donate, individually, is the practice of the person and cannot be regarded as an economic or legal matrix contract, but rather a relationship between people who respect each other and donate in reciprocity. That's why the charity to the poor or to the hungry, for example, would be humiliating because if on the one hand the recipient is not always able to reciprocate, or even more often is not allowed to make contact with those who donate, on the other side, the donor tries with this action to soothe their conscience in front of the difficulties of those who do not have the same economic possibilities.

It is the economic factor that often characterizes the exchanges between strangers in contemporary society, as specified by Kaiser (2017), who sees in modernity a complacency produced by the monetization of anything, making the gratuity of the gift something unpalatable, untied by the functionality and usefulness that any action must now include in itself (p. 28), I give you something to give something to me. There is in this dynamic a loss of authenticity because the giving has repercussions directly and immediately on what you will receive, drawing a monetarized exchange in which reciprocity is based precisely on reciprocating according to the value of what you are obtained, in an attempt to equal it. Or at most you try to reciprocate with a different value and maybe higher to show the generosity. In contrast, the generosity of giving must be an end in itself, given that the gift, by definition, is accompanied by feelings of freedom and gratuity.

In contemporary society, however, the educational demand in the relational practice is, in premise, precisely on the possibility, in truth urgent, to understand what kind of relationship can insist between a cultural and social evolution of the person and, of against, the real development of the subject itself when it is 
engaged in relationships of love and friendship, authentic, free, and profound. Knowing how to give and knowing how to receive, here, are pursued in the human of every subject in terms of love or friendship. It is the lack of availability of the individual to recreate different situations in the relationships between subjects: it seems, in fact, that modernity, with its charge of rationality and certainty, dismisses the person from the search for the encounter and the bond, laden with affectivity, subjectivity, and uncertainty. Humans have difficulty in wishing himself well, even before they love others: they risk not being able to sink into themselves breaking down their own foundation. The knot is the interpersonal relationship that, to put it with Bertolini (1988),

it is one of the perspectives on which the educational act is founded: the person of the educator is a pedagogical tool (to live with, to do with), the relationship is continuous, the daily life is used in a conscious and programmed way (p. 247).

Hence the importance of an educational relationship that looks at the meeting of two people in their humanity: only so educating becomes giving and receiving at the same time, because educating is to meet others, any other, to know and respect it, stimulating them to give authentic form to its humanity. It is not possible to educate while humanly estranged from the encounter: in the educational relationship there are at least two, each with its own being and with its own being-so. Those who educate give a part of themselves, and those who lend themselves to the benefit of others, not only donate materially but also, and above all, morally, in a dimension of solidarity and recognition of differences as the principle of equality.

\section{Help and educational practice report for a new life project}

The pedagogical intertwining between the professional and the human dimension makes it possible to re-read the turning point, in a decisive truth, which has occurred in recent years in 
the educational relationship. The action of the educator, in fact, is aimed at a student who personifies a being and a being so from the point of view of his own humanity as well as the status of subject of education, of receiving. A reception that is not at all passive, since education is not transmission, but exchange, just as in donating archaic societies; the student also contributes to the training of the professional educator who

it must be professionalized, that is to think and act as self and straight thoughtful worker endowed with a sufficient baggage of knowledge and skills that lean on a solid and thought motivational core (Tramma, 2016, p. 22).

The educational relationship, however, can't ignore an assessment, in the preamble, of the current conditions of society, where interpersonal relationships find difficulties in the process that involves both knowing how to do as well as knowing how to be. To understand the current era, then the contemporary person and his needs, in a key of project intervention in the educational processes, it is necessary to bring back to the time just passed (De Nicolò, 2005, p. 26). A person who relates, through a pedagogical relationship, in fact, implements in themself a change and contributes to the implementation of a transformation in the other, of the founding and expressive form of his humanity.

Being humanly determined, the relationship is therefore a privileged instrument of education, because it accepts the difference and recognizes the limit of the individual in the richness of the other by itself in the course of a time, not too short but not too long in the which identifies the educational relationship, useful and fundamental [...] to foster mutual involvement, to elaborate the conflict, to recognise the limit and to facilitate the process of change of which the other is the protagonist, in general, and the student in particular (Elia, 2017, pp. 132-133).

Thus, in education there is an exchange in reciprocity, in formative terms, which happens spontaneously because the 
educational relationship is not mechanical, preordained, or obliged. The practical act becomes an action, with the intention of rewriting its own project of life, and at the same time reacting to an idea deemed ineffective and unsatisfactory of its path of growth and formation. In volunteering, for example, this twofold phase of redundancy, reciprocity, respect, freedom and generosity is fully realised; it is the reception of the other, for what is humanly, in friendship and love, and presupposes an in-depth knowledge among those who relate to giving themselves and those who, in education, build in time when already giving, receiving, accepting are intertwined. According to Derrida (1996), the gift and the donation do not appear as such neither to those who donate nor to those who receive. This happens even when man spontaneously gives his life to save that of another, for the defense of an idea, to protect his land: there is no awareness of a donation, which is free from any expectation or claim to receive. In such contexts, the material life of humans acquires an essentially spiritual meaning (p. 16). The reference, once more, is to that relationship of help which, not resolving in the form of a consolatory or compensatory activity, can become a continuous discovery if understood as reciprocal dialectical exchange of individual and collective needs, place Hermeneutic open both inward and outward, dynamic, modifiable, in continuous movement. Knowing how to donate, as Lévinas said (1963), is in some way the general movement of spiritual life (p. 87). It is for this reason that the gift has, as a measure, the incalculable: there are no entries and exits that can be accounted for, there is no rationality able to assume the entity, it does not have the dynamics of the legal duty or the biological need; the gift places the deepest roots in gratuity. Hence the sense and the necessity of educating the meeting which, today more than yesterday, requires a slow and tiring process of knowledge both of anthropological assumptions and of the wide variety of communicative codes that insist on the relationship between people (Elia, 2017, p. 133). In conclusion, it is necessary to reflect on how an educational report devoted to the meeting may allow general responsible citizens to 
donate something belonging to their community, in a pedagogical key that opens up new and other knowledges of pedagogy and a new idea of volunteering. A humus vital for a life project that sees in others the differences that connote the aspect of equality of each person in the relationship with itself and with others, recalling the words of Morin (2001), which feels that we should bind our homily concentrically, and integrate them into the concrete universe of the terrestrial Homies (p. 78).

\section{Bibliography}

Annacontini G. (2006). Lo sguardo e la parola. Etnografia, cura e formazione. Bari: Progedit.

Annacontini G. (2012). Dalla mano al pensiero. Nessi, pedagogia e medicina. Lecce: Pensa Multimedia.

Baldacci M. (2010). Curricolo e competenze. Milano: Mondadori.

Baldacci M., \& Pinto Minerva F. (2015). Razionalità, educažione, realtà sociale. Studi sulla pedagogia di Franco Frabboni. Milano: FrancoAngeli.

Balzano V. (2017). Educazione, persona e welfare. Il contributo della pedagogia nello sviluppo delle politiche sociali. Bari: Progedit.

Bertolini P. (1988). L'esistere pedagogico. Ragioni e limiti di una pedagogia come scienza fenomenologicamente fondata. Firenze: La Nuova Italia.

Cagnolati A., Pinto Minerva F., \& Ulivieri S. (2013). Le frontiere del corpo. Mutamenti e metamorfosi. Pisa: ETS.

Cambi F. (2004). Saperi e competenze. Roma-Bari: Laterza.

De Nicolò M. (2005). Adulti in formazione: tra saperi e competenze. Lecce: Pensa Multimedia.

Derrida J. (1996). Donare il tempo. La moneta falsa. Milano: Cortina.

Elia G. (2014). A scuola di cittadinanza. Costruire saperi e valori etico-civili. Bari: Progedit.

Elia G. (2016). Prospettive di ricerca pedagogica. Bari: Progedit.

Elia G. (2017). La relazione educativa: strumento privilegiato del fare educazione. In S. Kanizsa \& A.M. Mariani (a cura di), Pedagogia generale (pp. 131-146). Milano-Torino: Pearson.

Frabboni F., \& Pinto Minerva F. (2014). Introdurione alla pedagogia generale. Bari: Laterza.

Hume D. (1992). Ricerca sui principi della morale. Roma-Bari: Laterza. 
Kaiser A. (2017). Per una pedagogia del dono. Firenze: Fupress.

Lévinas E. (1963). Difficile liberté. Paris: Albin Michel.

Loiodice I. (2008). Laicità ed eticità dell'azione pubblica. Libertà della persona e sfera pubblica. Bari: Cacucci.

Martini B. (2013). Pedagogia dei saperi. Problemi, luoghi e pratiche dell'educazione. Milano: FrancoAngeli.

Mauss M. (2002). Saggio sul dono. Forma e motivo dello scambio nelle società arcaiche. Torino: Einaudi.

Morin E. (2001). I sette saperi necessari all'educazione del futuro. Milano: Raffaello Cortina.

Nussbaum M.C. (2002). Giustiz̧ia sociale e dignità umana. Da individui a persone. Bologna: Il Mulino.

Pinto Minerva F., \& Gallelli R. (2004). Pedagogia e post-umano. Ibridazioni identitarie e frontiere del possibile. Roma: Carocci.

Tramma S. (2016). L'educatore imperfetto. Senso e complessità del lavoro educativo. Roma: Carocci Faber. 